\title{
Long Noncoding RNA CCDCI44NL-ASI Promotes the Oncogenicity of Osteosarcoma by Acting as a Molecular Sponge for microRNA-490-3p and Thereby Increasing HMGA2 Expression [Expression of Concern]
}

He J, Guan J, Liao S, et al. Onco Targets Ther. 2021;14: $1-13$.

The Editor and Publisher of OncoTargets and Therapy wish to publish an Expression of Concern for the published article. Following publication, concerns were raised about the scientific integrity of the articles content. We reached out to the authors requesting they supply information that would confirm the integrity of the data. The authors provided several files in response to our queries but they did not satisfy our requirements to confirm the authenticity of some types of data. In addition, there were unexplained similarities between some of the figures presented in this article, and figures presented in articles by different authors groups. As yet, the authors have not provided a satisfactory explanation for this.

Therefore, as we continue to work through the issues raised, we advise readers to interpret the information presented in the article with due caution.

The authors have been notified about this Expression of Concern.

\section{Publish your work in this journal}

OncoTargets and Therapy is an international, peer-reviewed, open access journal focusing on the pathological basis of all cancers, potential targets for therapy and treatment protocols employed to improve the management of cancer patients. The journal also focuses on the impact of management programs and new therapeutic agents and protocols on patient perspectives such as quality of life, adherence and satisfaction. The manuscript management system is completely online and includes a very quick and fair peer-review system, which is all easy to use. Visit http://www.dovepress.com/ testimonials.php to read real quotes from published authors. 